\title{
"The development of talent management in Malaysian public sector: a comprehensive review"
}

Sharmaine Sakthi Ananthan (D http://orcid.org/0000-0001-9175-7612

Halimah Abdul Manaf (D http://orcid.org/0000-0001-5391-9887

AUTHORS

Mega Hidayati (D http://orcid.org/0000-0002-8591-9395

Dian Suluh Kusuma Dewi (D) http://orcid.org/0000-0001-9867-617X

Sharmaine Sakthi Ananthan, Halimah Abdul Manaf, Mega Hidayati and Dian

ARTICLE INFO

Suluh Kusuma Dewi (2019). The development of talent management in Malaysian public sector: a comprehensive review. Problems and Perspectives in Management, 17(2), 242-253. doi:10.21511/ppm.17(2).2019.18

DOI

http://dx.doi.org/10.21511/ppm.17(2).2019.18

RELEASED ON

Thursday, 23 May 2019

RECEIVED ON

Thursday, 13 December 2018

ACCEPTED ON

Tuesday, 07 May 2019

\section{(c) EY}

LICENSE

This work is licensed under a Creative Commons Attribution 4.0 International License

JOURNAL "Problems and Perspectives in Management"

ISSN PRINT $1727-7051$

ISSN ONLINE $1810-5467$

PUBLISHER

LLC "Consulting Publishing Company "Business Perspectives"

FOUNDER

LLC "Consulting Publishing Company "Business Perspectives"

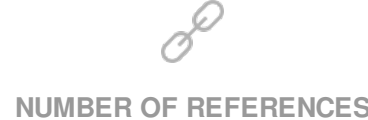

45
NUMBER OF FIGURES

0
NUMBER OF TABLES

9

(C) The author(s) 2022. This publication is an open access article. 


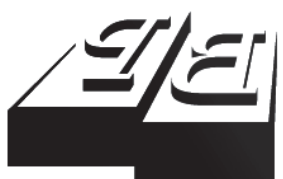

BUSINESS PERSPECTIVES

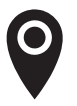

LLC "CPC "Business Perspectives" Hryhorii Skovoroda lane, 10, Sumy, 40022, Ukraine

www.businessperspectives.org

Received on: $13^{\text {th }}$ of December, 2018 Accepted on: $7^{\text {th }}$ of May, 2019

(c) Sharmaine Sakthi Ananthan, Halimah Abdul Manaf, Mega Hidayati, Dian Suluh Kusuma Dewi, 2019

Sharmaine Sakthi Ananthan, Ph.D., London School of Science and Technology (LSST), United Kingdom.

Halimah Abdul Manaf, Ph.D., School of Government, College of Law, Government and International Studies, Universiti Utara Malaysia, Kedah, Malaysia.

Mega Hidayati, Ph.D., Doctoral Program on Political Islam-Political Science, Universitas Muhammadiyah Yogyakarta, Indonesia.

Dian Suluh Kusuma Dewi, Lecturer Department of Government, Faculty of Social and Political Science, Universitas Muhammadiyah Ponorogo, Indonesia; Students of Doctoral Program, Political Islam-Political Science, Universitas Muhammadiyah Yogyakarta, Indonesia.

\section{(c) (i)}

This is an Open Access article, distributed under the terms of the Creative Commons Attribution 4.0 International license, which permits unrestricted re-use, distribution, and reproduction in any medium, provided the original work is properly cited.
Sharmaine Sakthi Ananthan (United Kingdom), Halimah Abdul Manaf (Malaysia), Mega Hidayati (Indonesia), Dian Suluh Kusuma Dewi (Indonesia)

\section{THE DEVELOPMENT OF TALENT MANAGEMENT IN MALAYSIAN PUBLIC SECTOR: A COMPREHENSIVE REVIEW}

\begin{abstract}
The aim of this current study was to analyze recent development of talent management among public service managers in Malaysia. The study brings understanding on talent management and broader human capital issues within Malaysia context by analysing the comprehensive literature. Government of Malaysia is emphasizing on development of talent in the public sector, as it is the most significant resource for the public service. The study found that the government has invested in various programs and initiatives to develop and produce key talented human capital within the public sector. However, despite the initiatives taken by the government, Malaysia is still short of talented people and struggling to develop talent, and talented skilful people are leaving. The study also indicated that year after year increasing number of graduates are being produced at the public universities, but the education system is not producing the right skilful individuals for the particular position or task, resulting in talent mismatch. Another key issue is the incapability to retain talented people that led to poor innovation and creativity within the country. Is key issue is part of the factors discussed in the $10^{\text {th }}$ and $11^{\text {th }}$ Malaysia Plan, and is a concern, as it plays a role in preventing the progress of Malaysia in achieving a developed nation by 2020. As one of the key aspirations of Malaysia is to enrich public service in Malaysia as a citizen centre that is having talented human capital. The study revealed that there is a need for in-depth quantitative and qualitative further research to discover new insights on talent management and retain talent among the public sector managers in Malaysia.
\end{abstract}

\section{Keywords \\ talent management, public sector, human capital, retain} talent

JEL Classification O15

\section{INTRODUCTION}

Talent management is seen to have created the interest of many academics and practitioners both within the public service and private sectors globally. Talent war is not something new, as it has been an on-going issue for the past 10 years, which has drawn interest of many researchers (Thunnissen et al., 2013), however, in the recent two years, it has become more complicated and though there has been many research done in the perspective of talent management, yet there is still no consensus of proper definition of talent management, theoretical backgrounds and scope (Gallardo-Gallardo et al., 2015). Some researchers have also criticized that talent management has limited by focusing on selective organizations, for instance, US-based organisations, and multinational (MNC's) and private organizations (Collings et al., 2011; Powell et al., 2013) and lack of emphasis is seen on the public sector in addition to shortage of empirical studies (Skuza et al., 2013). Talent management is important for country such as Malaysia that is moving towards being a developed country (Vaiman et al., 2012), whereby the government pays serious attention to increasing human capital through talent development (Tymon et al., 2010; Vaiman et al., 2012). 
Main pressure and emphasis are seen for much more focused aspects of talent management, as constant changes are seen in the environment globally in the recent years. This has resulted in shortage of skilful people, changing in the demographic aspects such as aging, gender diversification, educational aspects that increases the competition among talent that has huge impact on organizations today (Thunnissen et al., 2013; ManpowerGroup, 2015). In addition to that, transformations are seen from the perspective of businesses, for instance, moving forward from product-based to knowledge-based economies requires creative and innovation conceptual mind thinkers of employees to carry out such complex issues that look upon quality, skills, characteristics of talents that are in search (Schuler et al., 2011; Vaiman, Scullion, \& Collings, 2012).

As it is Malaysia's aspiration to be a developed nation by 2020, bearing this in mind, the government has entered into its final phase with the $11^{\text {th }}$ Malaysia Plan. The $11^{\text {th }}$ Malaysia Plan works towards helping Malaysia to strive the challenges and opportunities ahead positively towards being innovative to step up Malaysia's development. One of the key driving forces is the human capital development. In the $21^{\text {st }}$ century, where volatility, uncertainty, complexity and ambiguity are major concerns, the skilled human resources are known to be the most valuable asset.

It has been noted that great emphasis has been given to the public sector of Malaysia on the aspects of talent management and yet there is an on-going debate on creating and cultivating talents within the nation, especially in the public sector (EPU, 2016). The public sector is responsible for designing and monitoring policies practices (Taylor \& Wright, 2004), including being responsible for the governmental duties and regulations (Sandhu et al., 2011). Decisions that are carried out in the public sector have an impact on entire people and credibility of government itself. Therefore, it is vital to develop key potential talented public servants with the relevant key competencies to ensure efficient public service delivery. Studies and researchers have shown that Malaysia is struggling to retain talent (Nasir et al, 2012; EPU, 2016), this current study is carried out to assist the policy makers in terms of talent development, particularly among managers in public sector. The discussion of the study is expected to bring the understanding on talent development among managers in Malaysian public sector context to cultivate and transform skilful resources across the board to meet with the 2020 nation's mission. As such, the aim of this study is to identify key factors and prevailing issues on talent management in Malaysia and propose suggestions to minimize those issues on talent management among the Malaysian public service managers. The study contributes to the body of talent management literature with the main focus on the perspective of the Malaysian public sector servants from a developing country's viewpoint.

\section{THEORETICAL BASIS AND RESULTS}

\subsection{Talent management}

Talent management was first reviewed and introduced by the McKinsey Company in the end of 1990's. During the 1990's, the McKinsey Company was concerned about the aspects of talent and company performance and a research was carried out. The study was carried out in 1997 across 6,000 managers to investigate the measures undertaken by the successful firms that are capable to retain talented managers (Chambers et al., 1998). Assumptions were made on successful organizations to remain talented managers of the organization that has good mitiga- tion plans and process of the human resources management in place compared with the less effective organization. The study proved that the assumptions made were incorrect. It revealed that the processes of human resources management in both the effective organizations and less efficient organizations are at the same level. McKinsey Company's research further revealed that is it not the aspects of processes of human resources management that make organizations to be succeeding, but the key is the attitude of the leaders across the organization that makes the difference. Leader's attitude reflects the ability to remain and develop talent continuously with productivity heading to the organizations' visions.

This was the beginning of the talent management with specific individual capabilities in performing 
duties using knowledge, practical experience, best practices and strategic intelligence (Michaels et al., 2001). McKinsey (2009) asserts that talent is to choose the individuals that have potential and smart thinking. Smart (2005) supports the view and found that talented employees can be seen among top 10\% of employees in good rank of job positions and high salary. Similarly, Robertson and Abbey (2003) focus on managing the talent based on the best and the brightest. Robertson and Abbey (2003) further described that these individuals with the best and brightest can be categories as the exclusive group with high impact that have the ability to manage complexity, as they have wise strategic thinking.

In contrast to the above, talent management has been defined by many researchers in different terms and there is no one concrete or consensus on the definition of talent management. It is vital to acknowledge that there is non-informality in terms of talent management (Tansley, 2011). According to Tansley et al. (2007), talent is focused on individual characteristics that attracted different definition, but it can be noted that the common relation on the definition was organization-specific and evolved around the nature of work, vision and culture of the organization (Tansley et al., 2007; Iles, Chuai, \& Preece, 2010). Meyers and van Woerkom (2014) defined talent management as systematic process to identifying and filtering potential employees to grow and be highly committed with work. Gallardo-Gallardo et al. (2013) carried out their study on conceptualization of talent consisting of commitment, abilities to perform outstanding work and naturability. Meanwhile, Lewis and Heckman (2006) have defined talent management from different dimensions, including:

- talent management as part of human resources development;

- focus on the growth of human potential;

- leading human talent to organization productivity.

Collings and Mellahi (2009) described talent management from the perspective of job position as more valuable to the organizations rather than developing individual talent. Dries (2013) stresses that the inconsistency in the definitions of talent management leads organizations to have dis- crepancies between organization's intentions and practices. Table 1 shows variances of definitions of talent management by different researchers.

Table 1. Definition of talent

\begin{tabular}{|c|c|}
\hline Researchers & Definition \\
\hline $\begin{array}{l}\text { Lewis and Heckman } \\
(2006)\end{array}$ & $\begin{array}{l}\text { Talent able to create different image of } \\
\text { people }\end{array}$ \\
\hline Tansley et al. (2011) & $\begin{array}{l}\text { Talented employees have a significant } \\
\text { impact on organizational productivity } \\
\text { in the short or long term of working } \\
\text { duration }\end{array}$ \\
\hline Cheese et al. (2008) & $\begin{array}{l}\text { There are main elements of talent } \\
\text { consisting of attitudes, knowledge, } \\
\text { working experience and abilities of } \\
\text { people }\end{array}$ \\
\hline $\begin{array}{l}\text { Silzer and Dowell } \\
(2010)\end{array}$ & $\begin{array}{l}\text { Talent can be developed from employees } \\
\text { interest in the organization }\end{array}$ \\
\hline $\begin{array}{l}\text { Bethke-Langenegger } \\
\text { et al. (2011) }\end{array}$ & $\begin{array}{l}\text { Talent can be seen obviously from people } \\
\text { interest that helps to contribute to } \\
\text { organizational performance }\end{array}$ \\
\hline $\begin{array}{l}\text { Capelli and Keller } \\
\text { (2014) }\end{array}$ & $\begin{array}{l}\text { Talent involves employees in the job } \\
\text { description related with planning for } \\
\text { organizational strategies }\end{array}$ \\
\hline $\begin{array}{l}\text { Sparrow and } \\
\text { Makram (2015) }\end{array}$ & $\begin{array}{l}\text { It is combination of work commitment } \\
\text { and knowledge that contributes to people } \\
\text { competitive advantage }\end{array}$ \\
\hline
\end{tabular}

Despite the competing definitions on talent management, talent management and its perspective have transformed from being the 'old reality' (people need organization) to the 'new reality' (organisation needs people) (Chambers et al., 1998) (see Table 2). In the current century, many organizations, including public and private sectors locally and globally, are facing scare of skilful, talented people, though there are jobs, but organizations are unable to fill in that positions with the right person. It is vital to understand that in the present and in the future, there are bright prospects for talented individual to get job either in business, industry, government, non-governmental agencies or multinational companies.

Table 2. Comparison of different priorities in the past and present

Source: Michaels et al. (2001)

\begin{tabular}{|c|c|}
\hline The old reality & The new reality \\
\hline $\begin{array}{l}\text { Workers are looking for } \\
\text { employers }\end{array}$ & $\begin{array}{l}\text { Employers are looking for } \\
\text { talented workers }\end{array}$ \\
\hline $\begin{array}{l}\text { Equipment, money, land are } \\
\text { organization' capital }\end{array}$ & $\begin{array}{l}\text { Talented workers are } \\
\text { organization's asset }\end{array}$ \\
\hline Talent leads to small advantage & Talent leads to huge advantage \\
\hline Limited jobs are available & $\begin{array}{l}\text { Limited talented people are } \\
\text { available }\end{array}$ \\
\hline $\begin{array}{l}\text { Workers obey and have a } \\
\text { protected job }\end{array}$ & $\begin{array}{l}\text { Workers are mobile and have } \\
\text { various obligations }\end{array}$ \\
\hline $\begin{array}{l}\text { Workers are easily accepting } \\
\text { the job offered }\end{array}$ & $\begin{array}{l}\text { Workers are negotiating their } \\
\text { talent and return }\end{array}$ \\
\hline
\end{tabular}




\subsection{Key issues of talent management in the public sector of Malaysia}

Talent management is the key success of any organizations to sustain and remain competitive, similarly, at the public sector, it is vital to ensure that the talent is managed appropriately, as it resembles and portraits the country as a whole (Collings \& Mellahi, 2009). According to the CIPD survey (2012), only $6 \%$ of organizations consider that they have talent management systems to be effective. Thunnissen et al. (2013) claim that talent management if often than otherwise is overlooked, although organizations have pool of talent, but it is not going to success if the talent is unable to retain and develop. In order for the public sector in Malaysia to strengthen, the human capital is vital to identify, analyze and evaluate the existing issues of talent within the sector.

The main key issues under the talent management in the public sector of Malaysia are as follows:

1) Vision 2020 - to be able to have advancement in technology, well educated and trained public servants across the government bodies with the strength of networking towards achieving a developed nation and to be able to create sustainable development of skilful resources (OECD, 2013);

2) lack of potential employees with the right expertise and employability skills, including transferability skills (PwC, 2013);

3) talent mismatched - between skills demand and supply in job market (OECD, 2013);

4) weak productivity growth due to shortage of creativity and innovation in producing work and rely more on unprofessional workers (National Economic Advisory Council, 2010);

5) inability to attract talent has led to low innovation (NEAC, 2010).

Malaysia has taken various steps and measures to address the above issues and to be in line with the aim to drive towards the Vision 2020 with the national transformational framework to get the nation towards highly skilled workforce and into the developed economy (OECD, 2013). The measures that are taken will be discussed at length under the $10^{\text {th }}$ and $11^{\text {th }}$ Malaysian Plan, especially for the public sector in Malaysia, to develop the civil servants in the country. However, despite the measures taken, Malaysia is still lacking in managing their talents and to develop skilful resources (PwC, 2016).

\subsection{The economy of Malaysia}

In 2016, the population of Malaysia is approximately 31.7 million with $1.5 \%$ of population growth rate that are unevenly distributed among thirteen states (DOSM, 2016). Malaysia is also accommodating approximately 3.3 million of migrants and refugees (DOSM, 2016). The age structure of the population in Malaysia is as follows: majority of the Malaysian population are between the age of $16-64$ years $(69.4 \%)$, around $24.5 \%$ are between the age of $0-14$ years and $6 \%$ are 65 years and above (DOSM, 2016).

Malaysia has attained a strong ecomonic growth over the last twenty years and has become an upper income nation. With gradual succes achieved over the years, Malaysia's Prime Minister has developed a Vision for the country working towards 'The Vision 2020' that has an objective to be developed nation by 2020. In order to meet and achieve the objectives, various plans were set and government played many roles to develop the nation and one part of it is to develop potential calibre talented public servants in the country.

In 2013, Malaysia appeared to be the highest among upper-middle income countries in the World Economic Forum (WEF)'s first global Human Capital Index (HCI) ranking with a global rank of 22 (WEF, 2013). However, Malaysia was not able to sustain the ranking as after 3 years; Malaysia has dropped in the ranking to the $4^{\text {th }}$ placing among the upper-middle income nations and holding a global rank of 42 ( $\mathrm{PwC}, 2016)$. The index measurements consist of country's capability to grow and nurture accotding to healthy, educated workforce. Table 3 shows the comparison of the top 10 upper-middle income countries in World Economic Forum Human Capital Index Ranking for 2013 and 2016. This shows that Malaysia as a whole is struggling to strengthen the talent within the country. 
Table 3. Top 10 upper-middle income countries according to World Economic Forum (WEF) Human Capital Index Ranking

Source: PWC (2013), WEF (2016).

\begin{tabular}{|c|c|c|c|c|c|}
\hline \multirow[b]{2}{*}{ No. } & \multicolumn{2}{|c|}{2013} & \multirow[b]{2}{*}{ No. } & \multicolumn{2}{|c|}{2016} \\
\hline & Country & $\begin{array}{c}\text { Global } \\
\text { ranking }\end{array}$ & & Country & $\begin{array}{c}\text { Global } \\
\text { ranking }\end{array}$ \\
\hline 1 & Malaysia & 22 & 1 & Kazakhstan & 29 \\
\hline 2 & Costa Rica & 35 & 2 & Cuba & 36 \\
\hline 3 & Panama & 42 & 3 & Romania & 38 \\
\hline 4 & China & 43 & 4 & Malaysia & 42 \\
\hline 5 & Thailand & 44 & 5 & Bulgaria & 43 \\
\hline 6 & Kazakhstan & 45 & 6 & Thailand & 48 \\
\hline 7 & Mauritius & 47 & 7 & Panama & 52 \\
\hline 8 & Jordan & 52 & 8 & Ecuador & 53 \\
\hline 9 & Hungary & 54 & 9 & Azerbaijan & 54 \\
\hline 10 & Bulgaria & 56 & 10 & Mongolia & 55 \\
\hline
\end{tabular}

One of the initiatives taken by the government of Malaysia is embarked on a national transformation framework that has a main focus to become a high income country by 2020 . The national transformation framework comprises of three pillars:

- $\quad 10^{\text {th }}$ Malaysia Plan (2011-2015);

- new economic model (NEM);

- economic transformation program (ETP) that requires highly skilled and innovative workers as par as in developed countries (OECD, 2013).

In Malaysia, the $10^{\text {th }}$ Malaysia Plan between 2011 and 2015 focused on critical aspects of the government administration reform and strengthening human capital in public sector. Specifically, the $10^{\text {th }}$ Malaysia Plan agenda are:

- restructuring the existing government organisations structure and hierarchy;

- priorities to building national identity;

- creating performance measurement and assessment units;

- $\quad$ raising and maintaining talented and skilled workers in government services.

In addition to the $10^{\text {th }}$ Malaysia Plan, $11^{\text {th }}$ Malaysia Plan (2016-2020) was also introduced that stress- es the focus to strengthening talent management for public service of the future (EPU, 2016). The emphasis is made that talent within the public sector is crucial and is significant resource for the growing public service. It is vital to strengthen the talent management, capabilities and leadership for improved quality and services.

To achieve the $11^{\text {th }}$ Malaysia Plan (2016-2020) on strengthening talent management in the public sector, the following has been brought forward (EPU, 2016).

\section{Recruit employees on a contractual basis} to find talented employees. This is to invite specific and specialized talented skilful individual for available positions on a contractual basis within the public sector. Successful applicants would be given flexible pay and structured KPI's (Key Performance Indicators). This would eventually secure the talented employees and help the organizations to plan for development of human capital (EPU, 2016).

2. Flexibility of work schedules. The government will be open towards flexible working arrangement and accommodate to individual needs where possible to provide with a worklife-balance with much more flexibility within the public sector. Examples: flexible working hours, part-time opportunities to retain skilful individuals and minimize on new recruitment - this would encourage more women to consider or single parents - women that have to care for their children.

3. Empowering ministries to customize talent management. The government will bring in place a bottom-up approach to minimize the centralized approach. The agencies will plan and develop talent management programs based on the requirements and priorities. In addition to that, initiatives were taken to standardize performance evaluation based on individual roles and functions across each agency, introduce a standardized fair appraisal system in the public sector that enables rewards, job promotion, training and career path being offered equally to public servants (EPU, 2016). 
4. Competence and contemporary training approach. To enhance the leadership development by improved curriculum, courses and training programs by INTAN (National Institute of Public Administration) and RSOG (Razak School of Government) is to provide with the appropriate leadership capabilities in line with changes of public servants working attitude, mind set and public demands (EPU, 2016). The government also has to review the policies and procedures on the training policies to focus on developing transferable skills that would be beneficial to both the government and individual. It is to include newer perspective of multi-skills development, to develop training in varies fields and specialization such as green human resource, digitalization management, sustainability economy, forensic accounting, practical intelligence and learning development (EPU, 2016). It is also vital to restructure the public sector training institutes within greater specialization to support with the transformation and changes that are taking place in the current situation.

The aim of talent management within the public service sector is to provide pools of public servants with outstanding characteristics to serve public, stakeholder and sustain competitive advantage in the long run (EPU, 2016). Key importance to produce and retain talented skilful individuals in the public sector is that these individuals' frames set the image of the country. Though many initiatives were taken by the government to plan, organize and develop the talent in the public sector, there is still a long way to be successful in retaining the talent and skilful resources within the public sector.

\subsection{Public servants in Malaysia}

Malaysia is known to have the highest number of civil servants in the country and it is vital to recognize that to plan and manage 1.4 million public servants that deliver different type of services across three layers of government is highly complex that requires huge level of commitment, involvement, participation, effort and contribution of the public sector Human Resource (HR) managers (Chacko, 2015). There is a lot of work and involvement required for effective and efficient smooth transformation for the successful revolutionizing of the public service.

The government introduced the $10^{\text {th }}$ Malaysian Plan and $11^{\text {th }}$ Malaysia Plan to impulse the public sector to join hands and work as a group to create high impact services in aspects of social, economic, politic, technology, social and others. The concept and main aim of the public sector with the $10^{\text {th }}$ Malaysia Plan and $10^{\text {th }}$ Malaysia Plan is for the public service agencies to corporate and jointly work across different portfolio margins in achieving a shared common goal of the government to combat and retain skilful talented individuals. The government is emphasizing on the notion of "single purpose organizations" that aims to provide best-in-class public services to the citizens (EPU, 2016). This notion of the government can only be achieved if there are right skilful and talented employees in the private sector that are participating and working towards the common initiatives of the government.

Malaysia has recorded that the ratio of a civil servants per population as I: 19.37 people that represent huge number of public servants from entire citizens (Malaysia Digest, 2017). In Malaysia, there are $1,268,758$ public servants serving across more than 700 government agencies (including local authorities) (MOHR, 2015). Table 4 shows the number of male $(\mathrm{M})$ and female $(\mathrm{F})$ public servants across three main categories of job positions in public agencies, which consist of top management, professional and management group, and supportive group. The civil servants play an important role in the transformation and modernization of the country towards the challenges of becoming a developed nation by 2020 (Malaysia Digest, 2017). According to the Deputy Director General of Public Service Datuk Jalil Marzuki during his speech at the Malaysia's Journey towards high income advanced economy (August 9, 2016), "252 schemes of service in the public service were reviewed and number of schemes have reduced to 240 schemes" (Malaysia Productivity Cooperation, 2016, p. 23). The Jabatan Perkhidmatan Awam or known as the Public Service Department is accountable for managing human resource in public agencies. The Public Service Department is obligated by Suruhanjaya Perkhidmatan Awam (SPA) or the 
Table 4. Number of public servants in Malaysia (1995-2015)

Source: Ministry of Human Resource (2015).

\begin{tabular}{|c|c|c|c|c|c|c|c|c|c|c|c|c|}
\hline \multirow[t]{2}{*}{ Year } & \multicolumn{3}{|c|}{$\begin{array}{c}\text { Top management } \\
\text { (Grade Jusa C } \\
\text { (Supergrade) and } \\
\text { above) }\end{array}$} & \multicolumn{3}{|c|}{$\begin{array}{c}\text { Management and } \\
\text { professional } \\
\text { (Grade 41-54) }\end{array}$} & \multicolumn{3}{|c|}{$\begin{array}{l}\text { Supportive } \\
\text { (Grade 1-40) }\end{array}$} & \multicolumn{3}{|c|}{ Overall total } \\
\hline & M & $\mathbf{F}$ & Total & M & $\mathbf{F}$ & Total & M & $\mathbf{F}$ & Total & M & $\mathbf{F}$ & Total \\
\hline 1995 & 431 & 32 & 463 & 44,992 & 34,170 & 79,162 & 364,776 & 226,557 & 519,333 & 410,199 & 260,759 & 670,958 \\
\hline 1996 & 435 & 42 & 477 & 44,803 & 35,067 & 79,870 & 360,393 & 228,796 & 589,189 & 405,631 & 263,905 & 669,536 \\
\hline 1997 & 416 & 41 & 457 & 44,891 & 36,139 & 81,030 & 354,235 & 230,717 & 584,952 & 399,542 & 266,897 & 666,439 \\
\hline 1998 & 511 & 77 & 588 & 44,875 & 37,090 & 83,697 & 349,767 & 232,268 & 582,035 & 395,153 & 269,435 & 664,588 \\
\hline 1999 & 481 & 73 & 554 & 45,269 & 38,428 & 87,789 & 344,594 & 233,538 & 578,132 & 390,344 & 272,039 & 662,383 \\
\hline 2000 & 468 & 82 & 550 & 46,393 & 41,396 & 108,368 & 346,390 & 241,176 & 587,566 & 393,251 & 282,654 & 675,905 \\
\hline 2001 & 550 & 99 & 649 & 51,694 & 56,674 & 132,905 & 345,539 & 265,301 & 610,840 & 397,783 & 322,074 & 719,857 \\
\hline 2002 & 609 & 111 & 720 & 60,896 & 72,009 & 214,201 & 358,917 & 289,115 & 648,032 & 420,422 & 361,235 & 781,657 \\
\hline 2005 & 1,345 & 320 & 1,665 & 97,826 & 116,375 & 243,619 & 381,999 & 326,522 & 708,521 & 481,170 & 443,217 & 924,387 \\
\hline 2006 & 1,259 & 425 & 1,684 & 111,392 & 132,227 & 256,523 & 371,032 & 331,540 & 702,572 & 483,683 & 464,192 & 947,875 \\
\hline 2008 & 1,229 & 363 & 1,592 & 100,661 & 155,862 & 267,724 & 354,157 & 362,451 & 716,608 & 456,047 & 518,676 & 974,273 \\
\hline 2009 & 1,242 & 405 & 1,647 & 105,463 & 162,261 & 273,972 & 369,981 & 376,367 & 746,348 & 476,685 & 539,033 & $1,015,719$ \\
\hline 2010 & 1,086 & 519 & 1,605 & 107,041 & 166,931 & 277,284 & 376,116 & 387,536 & 763,652 & 484,243 & 554,986 & $1,039,229$ \\
\hline 2011 & 1,137 & 522 & 1,659 & 109,319 & 167,965 & 296,400 & 387,452 & 395,139 & 782,591 & 497,908 & 563,626 & $1,061,534$ \\
\hline 2012 & 1,966 & 752 & 2,718 & 114,159 & 182,241 & 331,313 & 381,553 & 394,242 & 775,795 & 497,679 & 577,235 & $1,074,913$ \\
\hline 2013 & 1,732 & 880 & 2,612 & 125,756 & 205,557 & 380,499 & 389,523 & 414,632 & 804,155 & 517,011 & 621,069 & $1,138,080$ \\
\hline 2014 & 2,559 & 1,260 & 3,819 & 136,824 & 243,675 & 501,953 & 387,038 & 430,328 & 817,366 & 526,421 & 675,263 & $1,201,684$ \\
\hline 2015 & 2,611 & 1,413 & 4,024 & 174,081 & 327,872 & 501,953 & 366,218 & 396,563 & 762,781 & 542,910 & 725,848 & $1,268,758$ \\
\hline
\end{tabular}

Public Services Commission, as they oversee the rules and regulation on managing public servants starting from appointment until retirement phase. It is vital for the government of Malaysia to develop and retain the existing public servants and to provide with the required training needs and skill development to ensure that each and every one of the public servants has the abilities and capabilities to deliver the required services to the public at large. At the same time, by developing and retain the existing public servants the government would be moving towards their Vision in achieving a developed nation.

\subsection{Education}

Education is an important aspect of building human capital and is the key to support the nation's objectives. It is worth to acknowledge that within the local public universities in Malaysia in 2015, there has been a total of 540,638 enrolment of students. Table 5 shows the detailed number of enrolment of students at each of the public universities in Malaysia. It is also noticed that high number of women is seen to be entering $63 \%$ in comparison to men $37 \%$; enrolment in the public universities of female students is $60 \%$ and male are $40 \%$; and the number of graduates for women is $63 \%$ in comparison to men $37 \%$ (see Tables 6 and 7). This shows that more women are seen to be more interested in further education in the public universities in comparison to men. Also 95\% of the students in the public universities comprises of local students and $5 \%$ are international students (see Table 8) (MOE, 2016). Most of the students are enrolled into the undergraduate programs $(78 \%)$, postgraduate programs (18\%) and $4 \%$ on other programs (Table 9). Table 9 indicates that undergraduate program consists of Diploma, Advanced Diploma and Degree, postgraduate program consists of Postgraduate Diploma, Master and Ph.D.; and others refer to Matriculation, Professional, Certificate and Pre-Session. These indicated that there has been development within the enrolment of tertiary education, in particular among women. This achievement is vital as Malaysia achieved universal primary education (MDG1) and gender equality in education (MDG3) in United Nations Development Program's Millennium Development Goals (United Nations, 2011).

These statistics in the education aspect indicates that women in Malaysia have invested in 
Table 5. Number of public universities enrolment

Source: Planning, Research and Policy Coordination Division, MOE (2016).

\begin{tabular}{|c|c|c|c|}
\hline No. & \multicolumn{2}{|c|}{ Public universities } & \multirow{2}{*}{$\frac{\text { Enrolment }}{27,452}$} \\
\hline 1 & Universiti Malaya & UM & \\
\hline 2 & Universiti Kebangsaan Malaysia & UKM & 27,239 \\
\hline 3 & Universiti Sains Malaysia & USM & 30,853 \\
\hline 4 & Universiti Putra Malaysia & UPM & 30,670 \\
\hline 5 & Universiti Teknologi Malaysia & UTM & 31,066 \\
\hline 6 & Universiti Utara Malaysia & UUM & 29,143 \\
\hline 7 & Universiti Islam Antarabangsa Malaysia & UIAM & 31,526 \\
\hline 8 & Universiti Malaysia Sarawak & UNIMAS & 16,962 \\
\hline 9 & Universiti Malaysia Sabah & UMS & 18,531 \\
\hline 10 & Universiti Sultan Pendidikan Sultan Idris & UPSI & 21,587 \\
\hline 11 & Universiti Teknologi MARA & UiTM & 174,755 \\
\hline 12 & Universiti Sultan Zainal Abidin & UniSZA & 9,947 \\
\hline 13 & Universiti Malaysia Terengganu & UMT & 10,665 \\
\hline 14 & Universiti Sains Islam Malaysia & USIM & 14,781 \\
\hline 15 & Universiti Tun Hussein Onn Malaysia & UTHM & 16,436 \\
\hline 16 & Universiti Teknikal Malaysia Melaka & UTeM & 12,370 \\
\hline 17 & Universiti Malaysia Pahang & UMP & 9,909 \\
\hline 18 & Universiti Malaysia Perlis & UnIMAP & 13,769 \\
\hline 19 & Universiti Malaysia Kelantan & UMK & 9,882 \\
\hline 20 & Universiti Pertahanan Nasional Malaysia & UPNM & 3,095 \\
\hline \multicolumn{3}{|l|}{ Total } & 540,638 \\
\hline
\end{tabular}

Note: Data as of October 2015 (updated May 18, 2016).

Table 6. Entrants, enrolment and graduates at public university by fields of study and gender

Source: Planning, Research and Policy Coordination Division, MOE (2016).

\begin{tabular}{|c|c|c|c|c|c|c|c|c|c|}
\hline \multirow{2}{*}{ Fields of study } & \multicolumn{3}{|c|}{ Entrants } & \multicolumn{3}{|c|}{ Enrolment } & \multicolumn{3}{|c|}{ Graduates } \\
\hline & M & $\mathbf{F}$ & $\mathbf{T}$ & M & $\mathbf{F}$ & $\mathbf{T}$ & M & $\mathbf{F}$ & $\mathbf{T}$ \\
\hline Education & 2,485 & 6,454 & 8,939 & 10,980 & 28,383 & 39,363 & 4,326 & 11,887 & 16,213 \\
\hline Arts and Humanities & 5,567 & 10,332 & 15,899 & 18,054 & 32,477 & 50,531 & 3,569 & 6,518 & 10,087 \\
\hline $\begin{array}{l}\text { Social Sciences, Business and } \\
\text { Law }\end{array}$ & 17,136 & 39,680 & 56,816 & 555,795 & 118,749 & 174,541 & 12,165 & 28,201 & 40,366 \\
\hline $\begin{array}{l}\text { Science, Mathematics and } \\
\text { Computer }\end{array}$ & 9,545 & 18,223 & 27,768 & 29,236 & 53,740 & 82,976 & 6,391 & 11,441 & 17,832 \\
\hline $\begin{array}{l}\text { Engineering, Manufacturing } \\
\text { and Construction }\end{array}$ & 19,670 & 17,224 & 36,894 & 68,357 & 56,382 & 124,739 & 13,921 & 11,157 & 25,078 \\
\hline Agriculture and Veterinary & 2,170 & 3,026 & 5,196 & 6,141 & 8,467 & 14,608 & 1,368 & 1,660 & 3,028 \\
\hline Health and Welfare & 2,346 & 6,564 & 8,910 & 9,223 & 24,547 & 33,770 & 1,674 & 4,497 & 6,171 \\
\hline Services & 2,647 & 4,229 & 6,876 & 7,258 & 11,746 & 19,004 & 1,684 & 2,453 & 4,137 \\
\hline General Program & 284 & 545 & 829 & 343 & 763 & 1,106 & 0 & 0 & 0 \\
\hline Total & 61,850 & 106,277 & 168,127 & 205,384 & 335,254 & 540,638 & 45,098 & 77,814 & 122,912 \\
\hline
\end{tabular}

Note: Data as of October 2015 (updated May 18, 2016).

Table 7. Percentage and ratio of students at public higher education institutes by gender

Source: Planning, Research and Policy Coordination Division, MOE (2016).

\begin{tabular}{c|c|c|c|c|c}
\hline \multicolumn{2}{c|}{ Males } & \multicolumn{2}{c|}{ Females } & \multicolumn{2}{c}{ Student ratio } \\
\hline Number & $\%$ & Number & $\%$ & Enrolment & Males to female \\
\hline 205,384 & 37.99 & 335,254 & 62.01 & 540,638 & $1: 1.63$ \\
\hline
\end{tabular}


Table 8. Enrolment and percentage of international students at public higher education institutes

Source: Planning, Research and Policy Coordination Division, MOE (2016).

\begin{tabular}{c|c|c|c|c}
\hline Local students & $\%$ & International students & $\%$ & Total \\
\hline 514,233 & 95.12 & 26,405 & 4.88 & 540,638 \\
\hline
\end{tabular}

Table 9. Enrolment and percentage of graduates at public higher education institutes

Source: Planning, Research and Policy Coordination Division, MOE (2016).

\begin{tabular}{c|c|c|c|c|c|c}
\hline Undergraduate & $\%$ & Postgraduate & $\%$ & Others & $\%$ & Total \\
\hline 421,820 & 78.02 & 95,753 & 17.71 & 23,065 & 4.27 & 540,638 \\
\hline
\end{tabular}

the preparation for career by considering higher education, where it is noticed that proportion of women in public universities in Malaysia now equal or greater than men. However, sadly, the rate of career development and opportunities for women within the position of managerial and professions is still continuing to be slow (Tarr-Whelan, 2009; Davidson \& Burke, 2011). Davidson and Burke (2011) stress that women in developing countries are seen to be gathering and preparing themselves all the necessary career advancements, but still struggling within the corporate growth.
In addition, despite this development seen in the education and with increase of graduates into the country, Malaysia is still handicapped by only having small number of workers that are skilled as compared with developed countries. It has been recorded that in Malaysia, skilled workers was only $25.5 \%$ in 2015 and $27.3 \%$ in 2016 (TalentCorp, 2016), against the OECD average of $37.6 \%$. It is encouraging to understand that the education background of the labor force is gradually improving. The share if tertiary educated labor force has increased by $1.8 \%$ as compared to 2015, this shows that more managerial, professional and technical roles are being filled.

\section{DISCUSSION AND CONCLUSION}

The current paper indicates that overall as a nation, Malaysia is still facing difficulties in developing talent and those talented skilful individuals in Malaysia are gradually leaving. Simultaneously, the education system is producing graduates each year, but these graduates are unable to fulfil the skills demanded by the organization. Malaysia's human capital situation is at the critical phrase not only with skill shortage, but also criticisms on lack of creativity and English proficiency, constantly has been ranked high among the top obstacles faced (NEAC, 2010). Comparing Malaysia on unskilled and semi-skilled labors with some of the advanced economies, for instance, Japan, Singapore, and Taiwan, indicates that Malaysia is still in higher rank of the group.

Government has taken tremendous measures with the $10^{\text {th }}$ and $11^{\text {th }}$ Malaysia Plan to compete and to identify that talented workers as valuable assets in the public sector for the growing economy to meet the status of a developed nation, however, this result is not satisfying, as there is still shortage of the dynamic talent. The government has introduced different program within the public sector to develop and attract skilled talent, but still unsuccessful. The government still requires aggressive improvement in developing the human capital by having higher value added activities (NEAC, 2010).

This research suggests that Malaysia's public sector has to reach out by committing, participating and to be involved in developing and enhancing the skills. Public servants must strive to make improvement and changes to develop the talent within the sector. The current study shows that the human capital in Malaysia is improving at a very slow pace. Malaysia is losing the skilled talent that is needed to drive 
the country into a developed country by 2020 and for further growth. In order for Malaysia to move closer towards the Vision 2020 and be a developed nation, investments with respective development plans have to be concise, focused, standardized across all government agencies and systematically avoid sector silos. Another suggestion is 'attitude of the leader' is vital within the public sector agencies, as it contributes to drive the sector towards making the differences. The leader's attitude is important in the development of talent and its activities towards emphasizing on continuous development, transferability skills and gradually the ability to strengthen the to retain and create the talent pool within the public sector. As the public sector plays a major role of the image of the country, it is suggested that proficiency of English language to be improved and the education system to develop the transferable skills, and skills requirements based to meet with the demand of the industry. These are needed, as Malaysia is at the core of a vibrant region and strategic location that draws interest of international investments that looks for innovative skills and offer value added and embrace new technology. In order to meet the international aspects, investment talent in Malaysia, especially in the public sector, has to be strengthened.

The paper fills in the gap in the talent management studies by contributing from a different perspective to exploring talent management aspects, especially for the public sector in Malaysia. Though previous studies have been carried out, the author believes that further in-depth quantitative and qualitative studies would provide with new insights on talent management and retaining talent of public servants in Malaysia. Therefore, perhaps future field study can examine differences of talent in the public and private sector.

\section{REFERENCES}

1. Bethke-Langenegger, P., Mahler, P., \& Staffelbach, B. (2011). Effectiveness of Talent Management Strategies. European Journal of International Management, 5(5), 524539. https://doi.org/10.1504/ EJIM.2011.042177

2. Cappelli, P., \& Keller, J. R. (2014). Talent Management: Conceptual Approaches and Practical Challenges. Annual Review of Organizational Psychology and Organizational Behavior, 1, 305331. https://doi.org/10.1146/ annurev-orgpsych-031413-091314

3. Chacko, J. G. (2015). UNDP: Support the public service transformation program. Retrieved from http://www.my.undp.org/ content/malaysia/en/home/operations/projects/democratic_governance/88281_PSTP.html

4. Chambers, E., Foulon, M., Handfield-Jones, H., Hankin, S., \& Michaels, E. G. (1998). The war for talent. The McKinsey Quarterly, 3(2), 44-57. Retrieved from https://www.researchgate.net/ publication/284689712_The_War_ for_Talent
5. Cheese, P., Thomas, R., \& Craig, E. (2008). The Talent Powered Organization: Strategies for Globalization, Talent Management and High Performance. Philadelphia, Pa.: Kogan Page.

6. Collings, D. G., \& Mellahi, K. (2009). Strategic Talent Management: A Review and Research Agenda. Human Resource Management Review, 19(4), 304-313. https://doi. org/10.1016/j.hrmr.2009.04.001

7. Collings, D. G., Scullion, H., \& Vaiman, V. (2011). European perspectives on talent management. European Journal of International Management, 5(5), 453-462. https://doi.org/10.1504/ EJIM.2011.042173

8. Davidson, M. J., \& Burke, R. J. (Eds.) (2011). Women in management worldwide (Vol. 2). Aldershot: Gower.

9. Department of Statistics Malaysia (DOSM). (2016). Current Population Estimates, Malaysia 2014-2016. Retrieved from https://www.dosm.gov. my/v1/index.php?r=column/ cthemeByCat\&cat=155\&bul_id $=$ O
WlxdEVoYlJCSOhUZzJyRUcvZEY xZz09\&menu_id=L0pheU43NWJ wRWVSZklWdzQ4TlhUUT09

10. Dries, N. (2013). The Psychology of Talent Management: A Review and Research Agenda. Human Resource Management Review, 23(4), 272-285. https://doi. org/10.1016/j.hrmr.2013.05.001

11. Economic Planning Unit (EPU). (2016). Government DeliveryTransforming the civil service to productivity (Chapter 9). In Eleventh Malaysia Plan 20162020. Kuala Lumpur: Percetakan Nasional Malaysia Berhad. Retrieved from https://policy. asiapacificenergy.org/sites/default/ files/11th\%20Malaysia\%20plan. pdf

12. Gallardo-Gallardo, E., Dries, N., \& González-Cruz, T. F. (2013). What is the meaning of 'talent' in the world of work? Human Resource Management Review, 23(4), 290300. http://dx.doi.org/10.1016/j. hrmr.2013.05.002

13. Gallardo-Gallardo, E., Nijs, S., Dries, N., \& Gallo, P. (2015). Towards an understanding of talent management as a 
phenomenon-driven field using bibliometric and content analysis. Human Resource Management Review, 25(3), 264-279. https://doi. org/10.1016/j.hrmr.2015.04.003

14. Iles, P., Chuai, X., \& Preece, D. (2010). Talent Management and HRM in Multinational companies in Beijing: Definitions, differences and drivers. Journal of World Business, 46(2), 179-189. https:// doi.org/10.1016/j.jwb.2009.09.014

15. Jamka, B. (2011). Czynnik ludzki we współczesnym przedsiębiorstwie: zasób czy kapitat? [The Human Factor in the Modern Enterprise: Resource or Capital?]. Warsaw: Wolters Kluwer business.

16. Lewis, R. E., \& Heckman, R. J. (2006). Talent Management: A Critical Review. Human Resource Management Review, 16(2), 139154. https://doi.org/10.1016/j. hrmr.2006.03.001

17. Malaysia Digest. (2017). M’sia Has The Highest Civil Service Workforce In The World, Is This A Misconception? Retrieved from http://www.malaysiandigest.com/ frontpage/282-main-tile/657488malaysia-s-bloated-civilservice-we-ask-stakeholdershow-to-justify-the-numbers.html (accessed on August 24, 20170.

18. Malaysia Productivity Corporation (MPC). (2016). Transformation in the public sector: Malaysia's Perspective. Retrieved from http://www.mpc.gov.my/ wp-content/uploads/2016/08/KPPA-for-APO-9Aug-2016-TKPPADATUK-JALIL.pdf

19. ManpowerGroup. (2015). 2015 Talent Shortage Survey. Retrieved from https://www. manpowergroup.com/wps/wcm/ connect/db23c560-08b6-485f9bf6-f5f38a43c76a/2015_Talent_Shortage_Survey_US-lo_res. pdf?MOD=AJPERES

20. Meyers, M. C., \& van Woerkom, M. (2014). The Influence of Underlying Philosophies on Talent Management: Theory, Implications for Practice, and Research Agenda. Journal of World Business, 49(2), 192-203.

21. Ministry of Education Malaysia (MOE). (2016). Quick Facts 2016
Malaysia Educational Statistics. Retrieved from https://www.moe. gov.my/index.php/menumedia/ media-cetak/penerbitan/terbitan/ buku-informasi/1586-quickfacts-2016/file

22. Ministry of Human Resource (MOHR). (2015). Statistic of Employment and Labor.

23. Nasir, A., Syed, S., \& Khabir, A. (2012).Managing Talent in Two Leading Companies in Malaysia. International Conference on Technology and Management Lecture Notes in Information Technology, 21, 125-130. Retrieved from https://www.researchgate. net/publication/263966866_Managing_Talent_in_Two_Leading_Companies_in_Malaysia

24. National Economic Advisory Council (NEAC). (2010). New Economic Model for Malaysia. Part 1: Strategic Policy Directions. Kuala Lumpur: Percetakan Nasional Malaysia Berhad. Retrieved from http://www.jcci.or.jp/NEM\%20 for $\% 20$ Malaysia $\% 20-\% 20$ Part $\% 20$ I_0.pdf

25. OECD. (2013). Structural Policy Country Notes. Malaysia. Retrieved from https://www.oecd. org/dev/asia-pacific/Malaysia.pdf

26. Powell, J., Duberley, J., Exworthy, M., MacFarlane, F., \& Moss, P. (2013). Has the British National Health Service (NHS) got talent? A process evaluation of the NHS talent management strategy. Policy Studies, 34(3), 291-309. http:// dx.doi.org/10.1080/01442872.201 3.798533

27. Price Waterhouse Coopers (PwC) (2013). Future of Government Series: Redefining Human Capital for a sustainable future. Retrieved from https://ww.pwc.com/my/en/ assets/publications/future-of-govthc.pdf

28. Robertson, A., \& Abbey, G. (2003) Managing talented people: Getting on with - and getting the best from - your high performers. Pearson Education Limited.

29. Sandhu, M. S., Jain, K. K., \& Ahmad, I. U. K. B. (2011). Knowledge sharing among public sector employees: evidence from Malaysia. International Journal of
Public Sector Management, 24(3), 206-226.

30. Schuler, R. S., Jackson, S. E., \& Tarique, I. (2011). Global Talent Management and Global Talent Challenges: Strategic Opportunities for IHRM. Journal of World Business, 46(4), 506-516.

31. Silzer, R., \& Dowell, B. E. (2010). Strategy-Driven Talent Management. San Francisco: Jossey-Bass. Retrieved from https://www.oreilly.com/library/ view/strategy-driven-talent-management/9780787988470/

32. Skuza, A., Scullion, H., \& McDonnell, A. (2013). An analysis of the talent management challenges in a post-communist country: the case of Poland. The International Journal of Human Resource Management, 24(3), 453-470.

33. Smart, B. (2005). Topgrading: How leading companies win by hiring, coaching, and keeping the best people. New York: Penguin Group.

34. Sparrow, P. R., \& Makram, H. (2015). What is the Value of Talent Management? Building ValueDriven Processes within a Talent Management Architecture. Human Resource Management Review, 25(3), 249-263.

35. TalentCorp. (2016). A Quick Glance at Malaysia. Retrieved from https://www.talentcorp.com. my/key-figures/key-figures

36. Tansley, C. (2011). What do we mean by the term "talent" in talent management? Industrial and Commercial Training, 43(5), 266-274.

37. Tansley, C., Turner, P., Foster, C., Harris, L., Stewart, J., Sempik, A., \& Williams, H. (2007). Talent: Strategy, management, measurement. London: CIPD. Retrieved from http://irep.ntu. ac.uk/id/eprint/6727/

38. Tarr-Whelan, L. (2009). Women Lead the Way: Your Guide to Stepping up to Leadership and Changing the World. San Francisco, CA: Berrett-Koehler.

39. Taylor, W. A., \& Wright, G. H. (2004). Organizational readiness 
for successful knowledge sharing: challenges for public sector managers. Information Resources Management Journal, 17(2), 2237. Retrieved from https://pdfs. semanticscholar.org/d462/646 4a35860a512219c2df247c3e75 7f27936.pdf

40. Thunnissen, M., Boselie, P., and Fruytier, B. (2013). A review of talent management: 'infancy or adolescence'? The International Journal of Human Resource Management, 24(9), 1744-1761. http://dx.doi.org/10.1080/0958519 2.2013.777543
41. Tymon, W. G., Stumpf, S. A., \& Doh, J. P. (2010). Exploring talent management in India: The neglected role of intrinsic rewards. Journal of World Business, 45(2), 109-121.

42. United Nations (UN). (2011). Malaysia: The Millennium Development Goals at 2010. Kuala Lumpur: Malaysia Country Team.

43. Vaiman, V., Scullion, H., \& Collings, D. G. (2012). Talent Management Decision Making. Management Decision,
50(5), 925-941. https://doi. org/10.1108/00251741211227663

44. WetFeet. (2009). The WetFeet Insider Guide to McKinsey \& Company. San Francisco, US: Wet-Feet inc. Retrieved from https://www.mcgill.ca/caps/ wetfeet-insider-guide-mckinseycompany-2009-ed

45. World Economic Forum (WEF). (2016). Human Capital Report 2016. Retrieved from http://reports.weforum.org/human-capital-report-2016/upper-middle/ 